\title{
POLA PENGELUARAN PANGAN RUMAH TANGGA MENURUT TINGKAT KETAHANAN PANGAN DI PROVINSI JAWA TENGAH
}

\author{
Yunastiti Purwaningsih 1, Slamet Hartono ${ }^{2}$, Masyhuri ${ }^{2}$, Jangkung Handoyo Mulyo ${ }^{2}$ \\ 1 Fakultas Ekonomi Universitas Sebelas Maret Surakarta \\ Jalan Ir. Sutami 36A Kentingan Surakarta 57126 Indonesia Telepon: +62-271-647481 \\ 2 Fakultas Pertanian Universitas Gadjah Mada Yogyakarta \\ Sekip Unit I, Yogyakarta 55281 Indonesia Telepon: +62 274519717
}

Diterima 27 Oktober 2010/Disetujui 10 Nopember 2010

\begin{abstract}
This research analyzes the system of food expenditure based on the household food security level in Central Java. The household food security levels are classified into four levels, consisting of food-secure, food-less secure, food-vulnerable and food-insecure. The data used are the Susenas data in the form of raw data. The results show that there are significant differences in the proportion of food expenditure among the households of food-secure and food-less secure to the households of food-vulnerable and food-insecure. In each level of household food-secure, household expenditure on instant foods and drinks shows the highest proportion compared to other food groups. The more insecure foods in a household, the higher expenditure proportion for tobacco. In each household group based on the level of food-secure, the households in urban areas have a smaller proportion of rice expenditure compared to the households in rural areas. Based on these results, hopefully the handling priority for the foodsecure problem should be better given to the household groups of food-vulnerable and foodinsecure.
\end{abstract}

Keywords: food expenditure, food security level, urban, rural

\begin{abstract}
Abstrak: Penelitian ini menganalisis pola pengeluaran pangan menurut tingkat ketahanan pangan rumah tangga di Jawa Tengah. Tingkat ketahanan pangan rumah tangga dikelompokkan menjadi empat, yaitu tahan, kurang, rentan dan rawan pangan. Data yang digunakan adalah data Susenas yang berupa data mentah. Hasil penelitian menunjukkan terdapat perbedaan yang cukup besar dalam proporsi pengeluaran pangan antara rumah tangga tahan dan kurang pangan dengan rumah tangga rentan dan rawan pangan. Pada setiap tingkat ketahanan pangan rumah tangga, pengeluaran rumah tangga untuk makanan-minuman jadi menunjukkan proporsi tertinggi dibanding dengan kelompok pangan lain. Semakin tidak tahan pangan suatu rumah tangga, semakin tinggi proporsi pengeluaran untuk tembakau. Pada setiap kelompok rumah tangga menurut tingkat ketahanan pangan, rumah tangga di wilayah perkotaan mempunyai proporsi pengeluaran beras lebih kecil dibanding dengan rumah tangga di wilayah pedesaan. Berdasar hasil tersebut disarankan bahwa prioritas penanganan masalah ketahanan pangan harus diberikan pada kelompok rumah tangga rentan dan rawan pangan.
\end{abstract}

Kata kunci: pengeluaran pangan, tingkat ketahanan pangan, kota, desa

\section{PENDAHULUAN}

Pola pengeluaran pangan rumah tangga telah menunjukkan perubahan dari pola pangan rumah ke pola pangan luar rumah. Selain itu juga terdapat kecenderungan meningkatnya konsumsi mie instan. Hasil analisis data runtut waktu Susenas yang dilakukan oleh Pusat Analisis Sosial Ekonomi dan Kebijakan Perta- 
nian serta Badan Ketahanan Pangan Departemen Pertanian menunjukkan (Ariani, 2008) bahwa pada tahun 2002, mie merupakan pangan pokok kedua, dan semakin signifikan pada tahun 2005, bahwa semua masyarakat di kota atau desa dan kaya atau miskin hanya mempunyai satu pola pangan pokok yaitu beras dan mie. Analisis lain dengan data data Susenas 1999, 2002 dan 2005 yang dilakukan oleh Saliem dan Ariningsih (2008) menunjukkan telah terjadi perubahan pola konsumsi dan pengeluaran rumah rangga di pedesaan Indonesia yang mengarah pada mie/terigu, serta meningkatnya konsumsi dan pengeluaran untuk makanan jadi dan rokok (tembakau dan sirih).

Berdasar latar belakang tersebut, penelitian ini menganalisis pola pengeluaran pangan rumah tangga menurut tingkat ketahanan pangan. Tingkat ketahanan pangan dilihat dari pendapatan rumah tangga dan konsumsi gizi rumah tangga (Johnson dan Toole, 1999 diadopsi oleh Maxwell et al., 2000 dalam Purwaningsih, 2008). Pendapatan rumah tangga menentukan daya beli, dan daya beli ini mencerminkan keterjangkauan pangan atau aksesibilitas rumah tangga terhadap pangan (Purwaningsih, 2008). Semakin tinggi pendapatan rumah tangga maka menunjukkan daya beli yang tinggi, dan rumah tangga semakin mudah mengakses pangan.

Dalam penelitian ini, pola pengeluaran pangan rumah tangga yang dikaji adalah rumah tangga di Provinsi Jawa Tengah, yang merupakan provinsi dengan pengeluaran rata-rata per kapita sebulan terendah dan proporsi pengeluaran pangan terbesar di Pulau Jawa. Menurut data BPS (2008a dalam Purwaningsih, 2010), pengeluaran rata-rata per kapita sebulan Provinsi Jawa Tengah adalah Rp281.365 (terendah di pulau Jawa) dibanding dengan Jawa Timur (sebesar Rp295.336), Jawa Barat (sebesar Rp367.263) dan Daerah Istimewa Yogyakarta (sebesar Rp390.369). Selanjutnya, proporsi pengeluaran makanan Jawa Tengah merupakan yang terbesar $(49,97$ persen dari total pengeluaran rumah tangga), dibanding dengan Jawa Timur (48,59 persen), Jawa Barat (49,15 persen) dan Daerah Istimewa Yogyakarta (41,80 persen). Apabila pengeluaran makanan di Jawa
Tengah diurai menurut komoditas, maka pengeluaran makanan dan minuman jadi merupakan porsi terbesar (yaitu sebesar 24,22 persen), disusul pengeluaran untuk padi-padian sebesar 21,43 persen.

\section{METODE PENELITIAN}

Tingkat ketahanan pangan rumah tangga diukur dengan indikator klasifikasi silang antara pangsa pengeluaran pangan dan kecukupan energi dari Jonsson dan Toole (1991) dalam Maxwell, D. et al. (2000). Pangsa pengeluaran pangan mengukur ketahanan pangan dari aspek ekonomi, sedangkan pemenuhan kecukupan konsumsi pangan dalam satuan energi mengukur ketahanan pangan dari aspek gizi (Saliem dan Ariningsih, 2008). Syarat kecukupan konsumsi energi sesuai dengan Widyakarya Nasional Pangan dan Gizi VIII (WKNPG) tahun 2004 adalah 2200 kkal/kapita/hari (LIPI, 2004 dalam Saliem dan Ariningsih, 2008). Tingkat ketahanan pangan dengan indikator tersebut ditabelkan pada Tabel 1. Berdasar Tabel 1 maka tingkat ketahanan pangan dikelompokkan menjadi 4 kelompok, yaitu tahan pangan, kurang pangan, rentan pangan dan rawan pangan.

Tabel 1. Tingkat Ketahanan Pangan Rumah Tangga

\begin{tabular}{|c|c|c|}
\hline \multirow{2}{*}{$\begin{array}{l}\text { Konsumsi Energi } \\
\text { per unit ekuivalen } \\
\text { dewasa }\end{array}$} & \multicolumn{2}{|c|}{ Pangsa pengeluaran pangan } \\
\hline & $\begin{array}{c}\text { Rendah } \\
(<60 \%)\end{array}$ & $\begin{array}{l}\text { Tinggi } \\
(\geq 60 \%)\end{array}$ \\
\hline $\begin{array}{l}\text { Cukup } \\
\text { (> 80\% kecukupan } \\
\text { energi) }\end{array}$ & $\begin{array}{l}\text { Tahan } \\
\text { pangan }\end{array}$ & $\begin{array}{l}\text { Rentan } \\
\text { pangan }\end{array}$ \\
\hline $\begin{array}{l}\text { Kurang } \\
(\leq 80 \% \text { kecukupan } \\
\text { energi) }\end{array}$ & $\begin{array}{l}\text { Kurang } \\
\text { pangan }\end{array}$ & $\begin{array}{l}\text { Rawan } \\
\text { pangan }\end{array}$ \\
\hline
\end{tabular}

Sumber: Jonsson dan Toole (1991) dalam Maxwell, D et al (2000).

Pangsa pengeluaran pangan merupakan rasio antara pengeluaran pangan terhadap total pengeluaran rumah tangga, dirumuskan sebagai berikut:

$P P P_{i}=\frac{P P_{i}}{T P}$ 
$P P P_{i}$ adalah pangsa pengeluaran pangan ke i, $P P_{i}$ adalah pengeluaran pangan ke $\mathrm{i}$ dimana $\mathrm{i}=$ $1,2,3, \ldots, 9$ yaitu beras, ketela, pangan hewani, lauk-pauk, buah, bahan minuman, mie, makanan-minuman jadi dan tembakau, TP adalah total pengeluaran rumah tangga. Konsumsi energi adalah jumlah kalori dari pangan yang dikonsumsi oleh rumah tangga.

Data yang digunakan adalah data Survei Sosial Ekonomi Nasional (Susenas) Panel 2008 (Maret) Modul Konsumsi/pengeluaran rumah tangga yang berasal dari Badan Pusat Statistik, berupa data mentah (raw data). Susenas Modul Konsumsi merupakan survei dengan unit observasi adalah rumah tangga. Jumlah rumah tangga yang dianalisis sebanyak 7.435 rumah tangga dari sejumlah 7.441 rumah tangga yang disurvei BPS untuk wilayah Provinsi Jawa Tengah (BPS, 2008d). Selisih rumah tangga tersebut merupakan data outlier, sehingga dihilangkan dari analisis.

Data Susenas yang digunakan meliputi data kor dan data konsumsi/pengeluaran. Data kor mengenai data karakteristik rumah tangga meliputi jumlah anggota rumah tangga, tingkat pendidikan kepala keluarga dan wilayah tempat tinggal (perkotaan/pedesaan). Data modul konsumsi/pengeluaran mengenai pembelian dan konsumsi rumah tangga terhadap makanan dan pengeluaran total rumah tangga. Dalam Susenas, item pengeluaran rumah tangga dibagi ke dalam 215 komoditas makanan dan 100 komoditas bukan makanan (BPS, 2008c).

Dalam penelitian ini dari sejumlah 215 komoditas makanan kemudian dikelompokkan ke dalam 9 kelompok, yaitu beras, ketela, pangan hewani, lauk-pauk, buah, bahan minuman, mie, makanan-minuman jadi dan tembakau. Dimasukkannya tembakau sebagai bagian dari komoditas pangan mengacu pada BPS yang mengelompokkan tembakau ke dalam pangan. Hubungan antara tembakau dengan pangan lainnya diduga dapat sebagai pangan pelengkap atau sebagai pengganti. Sebagai pelengkap, banyak ditemukan dalam kegiatan seperti merokok sambil minum (teh atau kopi atau minuman lainnya) dan atau makan camilan, serta kegiatan merokok setelah makan. Sebagai pengganti, banyak ditemukan pada sebagian orang yang tidak makan (biasanya pada pagi hari) dan menggantinya dengan merokok. Analisis pola pengeluaran pangan rumah tangga dilakukan secara diskripsi berupa tabel tunggal maupun silang.

\section{HASIL DAN PEMBAHASAN}

\section{Distribusi Rumah Tangga Menurut Tingkat Ketahanan Pangan}

Distribusi rumah tangga menurut tingkat ketahanan pangan di Jawa Tengah menunjukkan bahwa proporsi rumah tangga rentan pangan merupakan yang terbesar (35,62 persen) di antara empat tingkat ketahanan pangan yang ada, sedangkan rumah tangga tahan pangan sebesar 31,67 persen (Tabel 2).

Hasil penelitian ini yang menunjukkan bahwa proporsi rumah tangga rentan pangan merupakan yang terbesar, sama dengan hasil penelitian Rachman, Ariani dan Purwantini (2005) yang meneliti distribusi provinsi di Indonesia menurut derajat ketahanan pangan rumah tangga dengan data Susenas 1999 dan indikator yang sama, yaitu klasifikasi silang antara pangsa pengeluaran pangan dan kecukupan energi dari Johnson dan Toole (1991, dalam Maxwell et al, 2000). Hasil penelitian tersebut menyebutkan bahwa proporsi rumah tangga rentan pangan di Jawa Tengah yang terbesar (41,04 persen), disusul rawan pangan (38,94 persen), kurang pangan (10,45 persen) dan tahan pangan $(9,56$ persen). Apabila distribusi rumah tangga hasil penelitian Rachman, Ariani dan Purwantini tersebut dibandingkan dengan hasil penelitian ini (Tabel 2), maka proporsi rumah tangga tahan dan kurang pangan meningkat, sedangkan proporsi rumah tangga rentan dan rawan pangan menurun. Keadaan ini mengindikasikan perkembangan yang semakin baik, bahwa secara umum tingkat ketahanan pangan rumah tangga di Jawa Tengah membaik.

Distribusi rumah tangga dilihat menurut tingkat ketahanan pangan dan wilayah tempat tinggal (Tabel 2), menunjukkan bahwa sebagian besar rumah tangga tahan, rentan dan rawan pangan berada di pedesaan (berturut-turut 51,42 persen; 71,71 persen dan 65,13 persen) dan sebagian besar rumah tangga kurang pa- 
Tabel 2. Distribusi Rumah Tangga Menurut Tingkat Ketahanan Pangan dan Wilayah Tempat Tinggal di Provinsi Jawa Tengah

\begin{tabular}{lccc}
\hline \multirow{2}{*}{$\begin{array}{c}\text { Tingkat Ketahanan } \\
\text { Pangan }\end{array}$} & \multicolumn{2}{c}{ Wilayah } & Total \\
\hline Tahan & 1.144 & 1.211 & 2.355 \\
& $(39,11)$ & $(26,85)$ & $(31,67)$ \\
Kurang & $(48,58)$ & $(\mathbf{5 1 , 4 2 )}$ & $\mathbf{( 1 0 0 , 0 0 )}$ \\
& 586 & 567 & $\mathbf{1 . 1 5 3}$ \\
& $(20,03)$ & $(12,57)$ & $(15,51)$ \\
Rentan & $(50,82)$ & $(\mathbf{4 9 , 1 8 )}$ & $\mathbf{( 1 0 0 , 0 0 )}$ \\
& 749 & 1.899 & $\mathbf{2 . 6 4 8}$ \\
Rawan & $(25,61)$ & $(42,11)$ & $(35,62)$ \\
& $(\mathbf{2 8 , 2 9 )}$ & $\mathbf{( 7 1 , 7 1 )}$ & $\mathbf{( 1 0 0 , 0 0 )}$ \\
& 446 & 833 & $\mathbf{1 . 2 7 9}$ \\
Jumlah & $(15,25)$ & $(18,47)$ & $(17,20)$ \\
& $(34,87)$ & $(\mathbf{6 5 , 1 3 )}$ & $\mathbf{( 1 0 0 , 0 0 )}$ \\
& $\mathbf{2 . 9 2 5}$ & $\mathbf{4 . 5 1 0}$ & $\mathbf{7 . 4 3 5}$ \\
& $(100,00)$ & $(100,00)$ & $(100,00)$ \\
& $(39,34)$ & $(60,66)$ & $(\mathbf{1 0 0 , 0 0 )}$ \\
\hline
\end{tabular}

Sumber BPS. 2009. Susenas Panel Maret 2008 (data mentah), diolah.

Keterangan: * angka dalam kurung adalah persentase dari jumlah; * angka dalam kurung dan dicetak tebal adalah persentase dari total.

ngan berada di perkotaan (50,82 persen). Rumah tangga kurang pangan adalah rumah tangga yang mempunyai pangsa pengeluaran rendah namun kurang mengkonsumsi energi. Pangsa pengeluaran pangan rendah berarti kurang dari 60 persen bagian pendapatan dibelanjakan untuk pangan, dan ini mengindikasikan bahwa pendapatan yang diterima oleh kelompok rumah tangga tersebut relatif lebih tinggi dibanding dengan rumah tangga rentan pangan. Sementara rumah tangga rentan pangan dengan pendapatan yang dimiliki dapat memenuhi kecukupan energinya. Berdasarkan keadaan tersebut maka rumah tangga kurang pangan seharusnya merealokasi pengeluaran pangannya untuk memenuhi kecukupan energi. Untuk itu, diperlukan peningkatan pengetahuan pangan dan gizi, serta penyadaran tentang pentingnya memilih jenis dan jumlah pangan sesuai dengan norma gizi. Dengan pengetahuan tersebut, rumah tangga kurang pangan dapat mencapai tahan pangan.

Dilihat menurut wilayah tempat tinggal dan tingkat ketahanan pangan (Tabel 2), menunjukkan bahwa rumah tangga di perkotaan sebagian besar adalah tahan pangan (39,11 persen), disusul rentan (25,61 persen), rawan $(15,25$ persen) dan kurang pangan (20,03 persen). Selanjutnya di pedesaan menunjukkan sebagian besar rumah tangga adalah rentan pangan (42,11 persen), disusul tahan (26,85 persen), rawan (18,47 persen) dan kurang pangan $(12,57$ persen). Rumah tangga rentan pangan adalah rumah tangga yang mempunyai pangsa pengeluaran tinggi namun cukup mengkonsumsi energi. Pangsa pengeluaran pangan tinggi berarti lebih dari 60 persen bagian pendapatan dibelanjakan untuk pangan. Kondisi ini mengindikasikan rendahnya pendapatan yang diterima oleh kelompok rumah tangga tersebut. Namun demikian, dengan keterbatasan pendapatan yang dimiliki, rumah tangga rentan pangan dapat mengalokasikan pengeluaran pangannya sehingga dapat memenuhi kecukupan energi. Pada kelompok rumah tangga ini, pendapatan merupakan faktor utama untuk mencapai ketahanan pangan.

Temuan bahwa sebagian besar rumah tangga di pedesaan adalah rentan pangan lebih disebabkan oleh rendahnya pendapatan yang diterima. Keadaan ini diduga disebabkan relatif sempitnya kesempatan kerja di pedesaan dibanding dengan perkotaan, sehingga rumah tangga pedesaan mempunyai keterbatasan dalam hal sumber-sumber pendapatan. Dapat juga dinyatakan relatif lebih rendahnya pendapatan yang diterima dari pekerjaan yang tersedia di pedesaan. Berdasar temuan ini maka 
prioritas penanganan masalah ketahanan pangan sudah seharusnya diberikan di daerah pedesaan. Daerah pedesaan dibangun mengarah pada tersedianya peluang kerja, sehingga untuk memperoleh pendapatan yang lebih tinggi tidak perlu berpindah ke kota atau menglaju ke kota demi mendapat pekerjaan yang lebih baik. Pemerintah perlu memperluas akses rumah tangga pedesaan pada kegiatan yang dapat meningkatkan pendapatan rumah tangga, seperti melalui kegiatan pascapanen atau agroindustri, atau non-farm.

Selanjutnya rumah tangga rawan pangan, sebagian besar bertempat tinggal di wilayah pedesaan (Tabel 2). Rumah tangga rawan pangan adalah rumah tangga yang mempunyai pangsa pengeluaran tinggi dan kurang mengkonsumsi energi. Pangsa pengeluaran pangan tinggi berarti lebih dari 60 persen bagian pendapatan dibelanjakan untuk pangan. Ini mengindikasikan rendahnya pendapatan yang diterima oleh kelompok rumah tangga tersebut. Dengan rendahnya pendapatan yang dimiliki, rumah tangga rawan pangan dalam mengalokasikan pengeluaran pangannya tidak dapat memenuhi kecukupan energi. Pada kelompok rumah tangga ini, pendapatan dan pengetahuan gizi merupakan faktor untuk mencapai ketahanan pangan. Pendapatan yang meningkat disertai dengan pengetahuan tentang gizi, diharapkan kelompok rumah tangga ini dapat mencapai tahan pangan.

\section{Besarnya Pengeluaran Rumah Tangga Menurut Tingkat Ketahanan Pangan}

Pengeluaran rumah tangga terdiri dari pengeluaran pangan dan non pangan. Dilihat menu- rut tingkat ketahanan pangan, rumah tangga tahan pangan mempunyai rata-rata jumlah pengeluaran yang tertinggi (Rp1.519.938 sebulan) di antara kelompok rumah tangga lainnya. Data menunjukkan bahwa semakin tidak tahan pangan, maka rumah tangga mempunyai jumlah pengeluaran sebulan yang semakin sedikit (Rp1.139.779 untuk rumah tangga kurang pangan; Rp831.487 untuk rumah tangga rentan pangan dan Rp709.419 untuk rumah tangga rawan pangan). Rata-rata pengeluaran rumah tangga menurut tingkat ketahanan pangan dan wilayah tempat tinggal disajikan dalam Tabel 3.

Apabila pengeluaran rumah tangga dilihat menurut jenis pengeluaran, yaitu pangan dan non pangan (Tabel 3), menunjukkan rata-rata pengeluaran pangan sebulan untuk rumah tangga tahan dan rentan pangan (berturut-turut Rp644.549 dan Rp569.517) lebih besar dibanding rumah tangga kurang dan rawan pangan (masing-masing sebesar Rp493.933 dan Rp476.033). Untuk rata-rata pengeluaran non pangan sebulan menunjukkan semakin tidak tahan pangan suatu rumah tangga maka semakin kecil rata-rata pengeluarannya.

Dilihat proporsinya, yaitu proporsi jenis pengeluaran terhadap jumlah pengeluaran ( $\mathrm{Ta}$ bel 3), menunjukkan semakin tidak tahan pangan suatu rumah tangga maka semakin besar proporsi pengeluaran pangan dan semakin kecil proporsi pengeluaran non pangan. Ratarata proporsi pengeluaran pangan untuk rumah tangga tahan dan kurang pangan berturut-turut sebesar 42,41 persen dan 43,43 persen, sedangkan untuk rumah tangga rentan dan rawan pangan berturut-turut sebesar 68,49 persen dan 67,10 persen. Selanjutnya rata-rata proporsi pengeluaran non pangan untuk rumah tangga

Tabel 3. Rata-rata Pengeluaran Pangan dan Non Pangan Menurut Tingkat Ketahanan Pangan di Provinsi Jawa Tengah (dalam Rp/bulan)

\begin{tabular}{lccccc}
\hline \multirow{1}{*}{ Jenis } & \multicolumn{4}{c}{ Tingkat Ketahanan Pangan } & Total \\
\hline Pangan & Tahan & Kurang & Rentan & Rawan & \\
& 644.559 & 493.933 & 569.517 & 476.033 & $\mathbf{5 6 5 . 4 8 3}$ \\
Non Pangan & $(42,41)$ & $(43,43)$ & $(68,49)$ & $(67,10)$ & $(52,54)$ \\
& 875.38 & 645.847 & 261.97 & 233.386 & 510.878 \\
Jumlah & $(75,59)$ & $(56,66)$ & $(31,52)$ & $(32,90)$ & $(47,46)$ \\
& $\mathbf{1 . 5 1 9 . 9 3 8}$ & $\mathbf{1 . 1 3 9 . 7 7 9}$ & $\mathbf{8 3 1 . 4 8 7}$ & $\mathbf{7 0 9 . 4 1 9}$ & $\mathbf{1 . 0 7 6 . 3 6 1}$ \\
& $(100,00)$ & $(100,00)$ & $(100,00)$ & $(100,00)$ & $(100,00)$ \\
\hline
\end{tabular}

Keterangan: angka yang dicetak miring adalah persentase dari jumlah.

Sumber: BPS. 2009. Susenas Panel Maret 2008 (data mentah), diolah. 
tahan, kurang, rentan dan rawan pangan berturut-turut sebesar 75,59 persen; 56,66 persen; 31,52 persen dan 32,90 persen. Nampak perbedaan proporsi pengeluaran, baik pangan maupun non pangan, antara rumah tangga tahan dan kurang pangan dengan rumah tangga rentan dan rawan pangan, cukup besar. Fenomena ini menandakan kesejahteraan rumah tangga pada kedua kelompok ketahanan pangan jauh berbeda. Berdasar kenyataan tersebut maka prioritas penanganan masalah ketahanan pangan harus diberikan pada kelompok rumah tangga rentan dan rawan pangan. han dan rentan pangan mempunyai jumlah pengeluaran pangan lebih besar dibanding rumah tangga kurang dan rawan pangan. Rumah tangga tahan dan rentan pangan dilihat dari kecukupan energi adalah rumah tangga dengan energi yang cukup, rumah tangga kurang dan rawan pangan adalah rumah tangga dengan energi yang kurang. Dengan demikian dapat dinyatakan rumah tangga dengan energi yang cukup mempunyai jumlah pengeluaran pangan yang lebih besar dibanding rumah tangga dengan energi yang kurang.

Jumlah pengeluaran pangan rumah tangga dan terkecil adalah rumah tangga rawan pangan (Rp109.479/minggu). Rumah tangga ta- rentan dan rawan pangan (berturut-turut 10,73 
persen dan 10,37 persen) (Tabel 4). Pangan hewani merupakan komoditas pangan yang harganya relatif mahal dibanding dengan komoditas pangan lainnya. Dihubungkan dengan pendapatan rumah tangga yang diproksi dari jumlah pengeluaran rumah tangga, berdasar data menunjukkan rumah tangga tahan dan kurang pangan mempunyai pendapatan yang relatif lebih tinggi dibanding dengan rumah tangga rentan dan rawan pangan (Tabel 3), sehingga dapat dipahami apabila rumah tangga tahan dan kurang pangan mempunyai proporsi pengeluaran pangan hewani yang lebih besar dibanding dengan rumah tangga rentan dan rawan pangan.

Proporsi pengeluaran beras untuk rumah tangga kurang dan rawan pangan (berturutturut 17,22 persen dan 19,53 persen) lebih besar dibanding dengan rumah tangga tahan dan rentan pangan (berturut-turut 12,53 persen dan 16,16 persen) (Tabel 4). Rumah tangga kurang dan rawan pangan dilihat dari kecukupan energi adalah rumah tangga dengan energi yang kurang ( $\leq 80$ persen kecukupan energi), sedangkan rumah tangga tahan dan rentan pangan adalah rumah tangga dengan energi yang cukup (>80 persen kecukupan energi). Berdasar hasil tersebut dapat dinyatakan bahwa rumah tangga dengan energi yang kurang mempunyai proporsi pengeluaran beras yang lebih besar dibanding dengan rumah tangga dengan energi yang cukup.

Proporsi pengeluaran tembakau pada setiap tingkat ketahanan pangan rumah tangga (Tabel 4) merupakan proporsi dengan urutan ke empat (sebesar 7,69 persen untuk rumah tangga tahan pangan; 8,69 persen untuk rumah tangga kurang pangan; 9,84 persen untuk rumah tangga rentan pangan dan 10,40 persen untuk rumah tangga rawan pangan) setelah makanan dan minuman jadi, lauk-pauk, pangan hewani dan beras. Proporsi tembakau ini melebihi proporsi pengeluaran buah, bahan minuman, mie dan ketela (kesemuanya masing-masing kurang dari 6 persen). Data tersebut menunjukkan semakin tidak tahan pangan suatu rumah tangga, semakin tinggi proporsi pengeluaran untuk tembakau, atau dengan pernyataan lain rumah tangga rawan pangan mempunyai alokasi pengeluaran tembakau yang paling banyak di- banding dengan kelompok rumah tangga lainnya.

Temuan bahwa rumah tangga rawan pangan mempunyai alokasi pengeluaran tembakau terbesar dibanding kelompok rumah tangga lainnya senada dengan hasil penelitian Saliem dan Ariningsih (2008) dengan data Susenas Panel 1999, 2002 dan 2005 untuk rumah tangga pedesaan Indonesia. Hasil penelitian tersebut menunjukkan bahwa rumah tangga pedesaan Indonesia, khususnya kelompok rawan pangan, pengeluaran tembakau mengalami peningkatan dari 9 persen pada tahun 1999 menjadi 14 persen pada tahun 2005. Data menunjukkan rumah tangga rawan pangan adalah rumah tangga dengan pendapatan paling rendah di antara empat kategori ketahanan pangan rumah tangga (Tabel 3), sehingga rumah tangga rawan pangan perlu melakukan realokasi pola pengeluaran pangan yang dapat meningkatkan ketahanan pangannya, utamanya mengurangi pengeluaran untuk tembakau dan menambah pengeluaran bahan pangan lainnya.

Menurut Saliem dan Ariningsih (2008), secara umum tingginya proporsi pengeluaran tembakau perlu diwaspadai, mengingat merokok tidak direkomendasikan dari segi kesehatan, sehingga perlu sosialisasi, edukasi dan advokasi tentang bahaya merokok bagi kesehatan. Terlebih untuk rumah tangga rawan pangan, sosialisasi, edukasi dan advokasi tentang bahaya merokok bagi kesehatan perlu dilakukan dengan lebih intensif. Pemerintah perlu melakukan pelarangan melalui himbauan serta menyediakan tempat/ruangan khusus merokok di tempat publik, membuat peraturan bagi yang merokok di sembarang tempat, mensosialisasikannya dan menegakkannya dengan tegas.

Menurut tingkat ketahanan pangan dan wilayah tempat tinggal di Jawa Tengah (Tabel 4), rata-rata jumlah pengeluaran pangan rumah tangga di wilayah perkotaan lebih besar (Rp155.323/minggu) dibanding dengan rumah tangga di wilayah pedesaan (Rp117.393/ming$\mathrm{gu}$. Kondisi yang sama berlaku untuk rata-rata jumlah pengeluaran pangan menurut wilayah dan tingkat ketahanan pangan, bahwa pada setiap kelompok rumah tangga menurut tingkat 
ketahanan pangan, rumah tangga di wilayah perkotaan mempunyai rata-rata jumlah pengeluaran pangan lebih besar dibanding dengan rumah tangga di wilayah pedesaan. keadaan ini yang menyebabkan rumah tangga di pedesaan mempunyai proporsi pengeluaran pangan hewani yang lebih kecil dibanding dengan rumah tangga di perkotaan. dengan rumah tangga di wilayah pedesaan. Temuan ini dihubungkan dengan harga pangan hewani dan pendapatan rumah tangga (yang diproksi dari jumlah pengeluaran rumah tangga), bahwa harga pangan hewani relatif mahal dibanding pangan lainnya, serta pendapatan rumah tangga pedesaan yang relatif lebih kecil dibanding rumah tangga perkotaan, maka nambah pengeluaran untuk pangan lainnya.

Proporsi pengeluaran buah, bahan minuman, mie dan ketela, pada setiap tingkat ketahanan pangan, baik rumah tangga di perkotaan maupun di pedesaan, kesemuanya masing-masing kurang dari 6 persen (Tabel 4). 


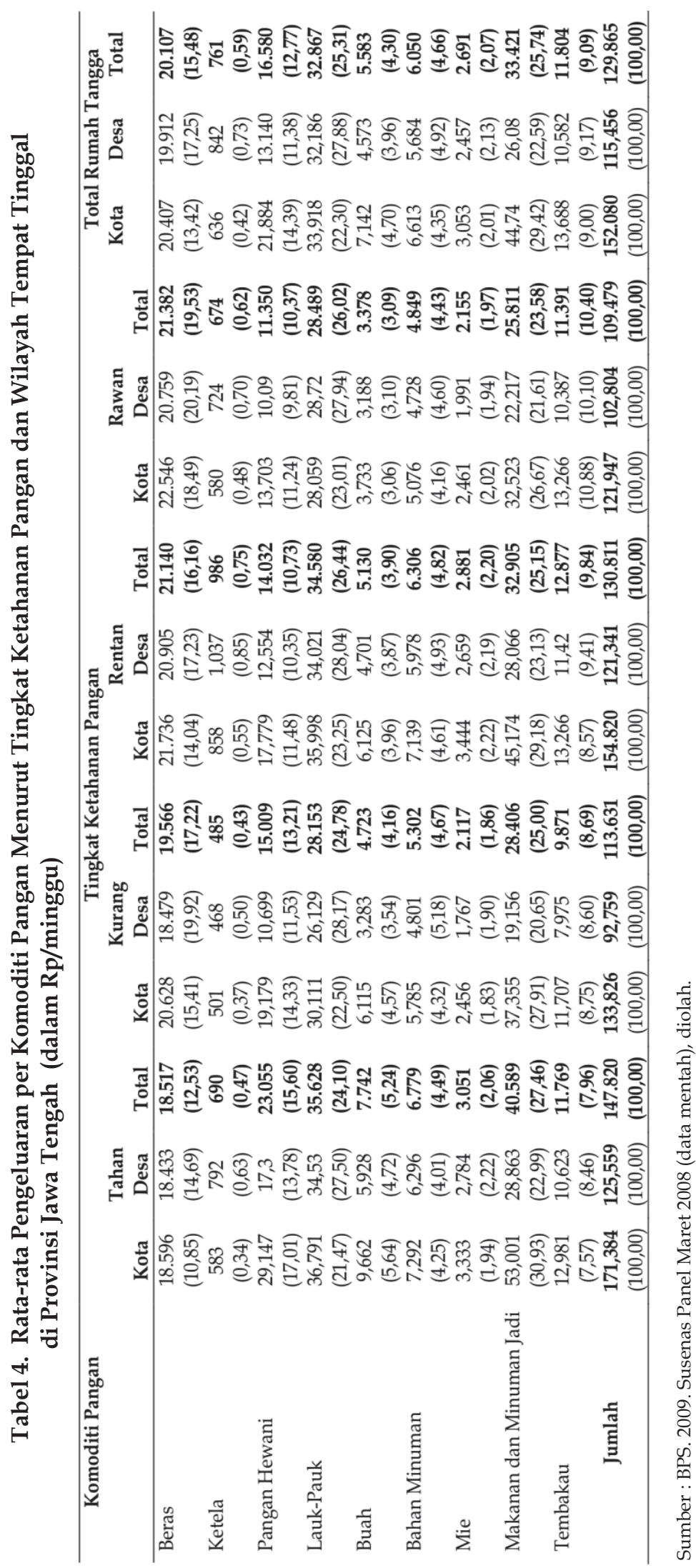


Untuk proporsi pengeluaran buah dan bahan minuman lebih besar rumah tangga di perkotaan dibanding di pedesaan; proporsi pengeluaran mie rumah tangga tahan dan kurang pangan lebih besar di pedesaan dibanding di perkotaan, sedangkan rumah tangga rentan dan rawan pangan sebaliknya, lebih besar di perkotaan dibanding di pedesaan; proporsi pengeluaran ketela lebih besar rumah tangga di pedesaan dibanding di perkotaan (Tabel 4).

\section{Besarnya Pengeluaran per Komoditas Pangan Bukan dari Pembelian}

Komoditas pangan yang dikonsumsi oleh rumah tangga berasal dari pembelian dan bukan pembelian. Pangan yang berasal dari bukan pembelian merupakan pangan produksi sendiri, pemberian, dan sebagainya (BPS, 2008c). Rata-rata pangan bukan pembelian rumah tangga di Jawa Tengah sebesar Rp14.680/ minggu atau 11,30 persen dari jumlah keseluruhan pangan. Menurut komoditas pangan, rata-rata pangan bukan pembelian terbesar adalah makanan-minuman jadi Rp4.535/minggu (30,89 persen) dan beras Rp4.063/minggu (27,61 persen), disusul lauk-pauk Rp2.292/ minggu (15,61 persen) dan buah Rp1.571/ minggu (10,70 persen). Rata-rata pangan bukan pembelian terkecil adalah bahan minuman Rp103/minggu (0,70 persen) dan mie Rp30/ minggu (0,20 persen). Menurut tingkat ketahanan pangan, adanya perbedaan rata-rata pengeluaran pangan bukan pembelian di antara kelompok rumah tangga. Selengkapnya dapat dilihat dalam Tabel 5.

Berdasar data Tabel 5, rumah tangga rentan pangan mempunyai rata-rata yang terbesar (Rp17.929 seminggu atau 13,71 persen), disusul rumah tangga rawan pangan (Rp13.167 seminggu atau 12,03 persen), rumah tangga tahan pangan (Rp14.305 seminggu atau 9,68 persen), dan yang terkecil adalah rumah tangga kurang pangan (Rp9.665 seminggu atau 6,54 persen). Rumah tangga rentan dan rawan pangan adalah rumah tangga yang mempunyai pendapatan lebih kecil dibanding dengan dua kelompok rumah tangga lainnya (Tabel 5), sehingga bisa dipahami apabila rata-rata pangan bukan pembelian pada kedua kelompok rumah tangga tersebut lebih besar dibanding dengan dua kelompok rumah tangga lainnya.

Rata-rata pengeluaran pangan bukan pembelian dilihat menurut tingkat ketahanan pangan dan per komoditas pangan (Tabel 5), pada tiga kelompok rumah tangga menurut tingkat ketahanan pangan, yaitu tahan pangan, rentan dan rawan pangan, menunjukkan pola yang sama dengan total rumah tangga di Jawa Tengah, rata-rata pangan bukan pembelian terbesar adalah makanan-minuman jadi dan beras, disusul lauk-pauk dan buah. Pada rumah tangga kurang pangan, rata-rata pangan bukan pembelian terbesar adalah beras dan makananminuman jadi, disusul lauk-pauk dan buah. Rata-rata pangan bukan pembelian terkecil pada setiap kelompok rumah tangga adalah bahan minuman dan mie.

Menurut tingkat ketahanan pangan dan wilayah tempat tinggal di Jawa Tengah (Tabel 5), secara total rumah tangga menunjukkan adanya perbedaan rata-rata pengeluaran pangan bukan pembelian antara rumah tangga perkotaan dan pedesaan. Rata-rata pangan bukan pembelian rumah tangga di wilayah pedesaan (Rp16.976 seminggu atau 14,70 persen) lebih besar dibanding dengan rumah tangga di wilayah perkotaan (Rp11.141 seminggu atau 7,33 persen). Hasil ini menunjukkan rumah tangga di wilayah pedesaan mempunyai ratarata pangan bukan pembelian hampir dua kali lipat dibanding rumah tangga di wilayah perkotaan. Kondisi yang sama berlaku untuk ratarata pangan bukan pembelian menurut wilayah dan tingkat ketahanan pangan, bahwa pada setiap kelompok rumah tangga menurut tingkat ketahanan pangan, rumah tangga di wilayah pedesaan mempunyai rata-rata pangan bukan pembelian lebih besar dibanding dengan rumah tangga di perkotaan, hampir dua kali lipat.

Lebih besarnya pangan bukan pembelian pada rumah tangga di wilayah pedesaan dibanding rumah tangga di wilayah perkotaan, disebabkan pedesaan adalah penghasil pangan dan perkotaan bukan penghasil pangan. Sebagai penghasil pangan, rumah tangga di pedesaan dapat memenuhi kebutuhan pangan melalui produksi sendiri, menanam tanaman pangan di pekarangan, ladang ataupun sawah. Rumah tangga juga dapat memenuhi kebutuhan pangan hewani dengan beternak sendiri. 


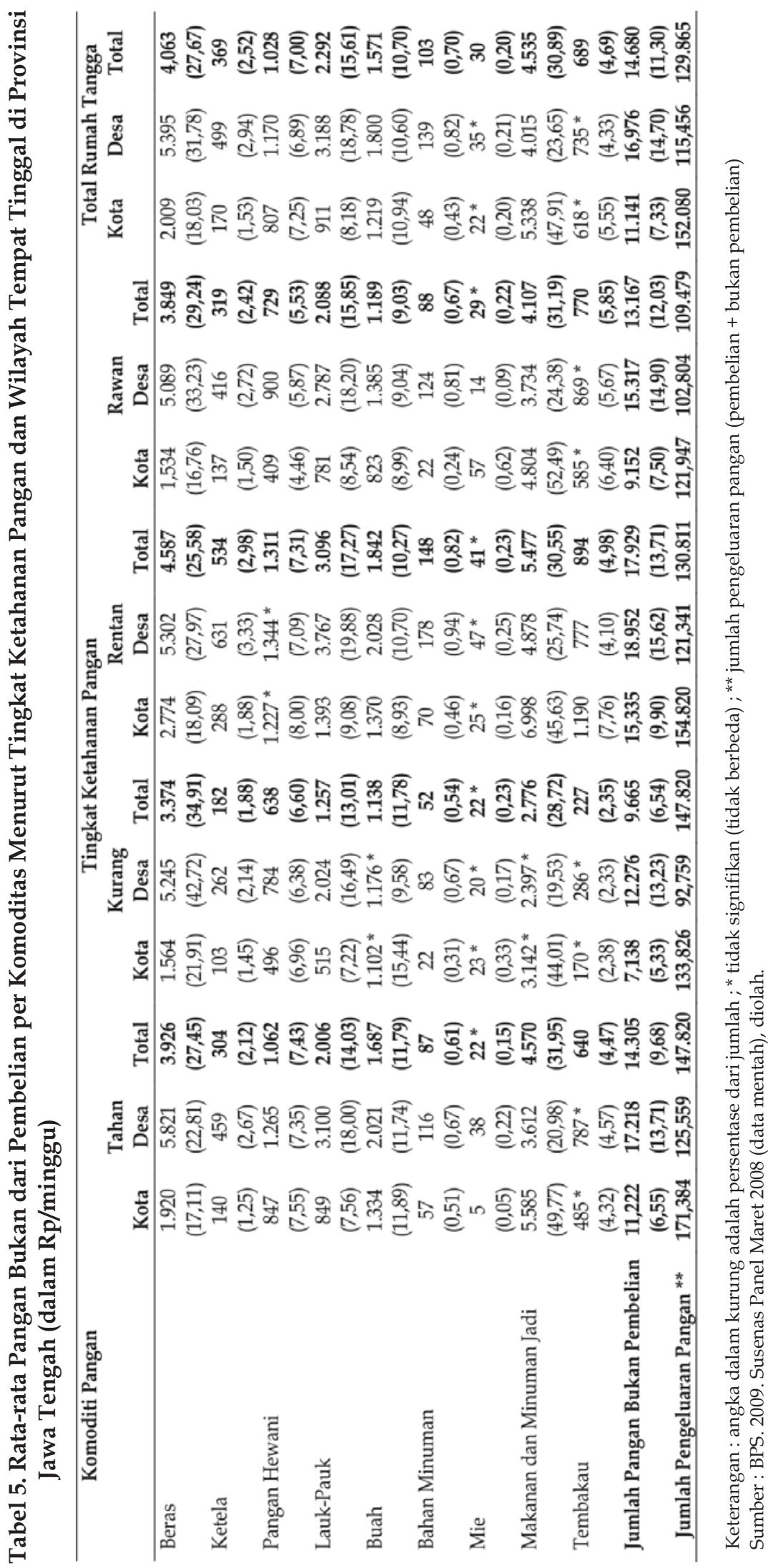


Dilihat menurut komoditas pangan, setiap rumah tangga menurut wilayah dan tingkat ketahanan pangan menunjukkan adanya perbedaan rata-rata pengeluaran pangan bukan pembelian di antara kelompok rumah tangga pada sebagian besar komoditas pangan. Pada komoditas pangan mie, tidak terdapat perbedaan rata-rata mie bukan pembelian antara perkotaan dan pedesaan serta rumah tangga menurut tingkat ketahanan pangan, kecuali rumah tangga tahan pangan. Pada makananminuman jadi hanya pada rumah tangga kurang pangan yang menunjukkan tidak ada perbedaan antara perkotaan dan pedesaan. per komoditas pangan menurut tingkat ketahanan pangan dan wilayah tempat tinggal dapat dilihat dalam Tabel 6.

Pangsa pengeluaran pangan menurut tingkat ketahanan pangan, rumah tangga tahan dan kurang pangan mempunyai pangsa pengeluaran lebih kecil (masing-masing 0,4576 untuk tahan pangan dan 0,4662 untuk kurang pangan) dibanding kelompok rumah tangga rentan dan rawan pangan (masing-masing 0,6803 untuk rentan pangan dan 0,6676 untuk rawan pangan) (Tabel 6).

Menurut alokasi per komoditas pangan (Tabel 6), secara total rumah tangga, rata-rata añ pangan, rumah tangga tahan dan rentan pangan mempunyai rata-rata nilai pengeluaran pangan sebulan (masing-masing Rp633.524 untuk tahan pangan dan Rp560.617 untuk rentan pangan) lebih besar dibanding kelompok rumah tangga kurang dan rawan pangan (masing-masing Rp486.990 untuk kurang pangan dan Rp469.195 untuk rawan pangan). Selengkapnya rata-rata nilai dan pangsa pengeluaran
0,0659 berturut-turut untuk rumah tangga tahan, rentan dan rawan pangan). Pangsa pengeluaran tembakau rumah tangga rawan dan rentan pangan merupakan yang terbesar (berturut-turut 0,0646 dan 0,0601) diantara empat katagori tingkat ketahanan pangan yang ada (0,0339 dan 0,0360 berturut-turut untuk rumah tangga tahan dan kurang pangan). 


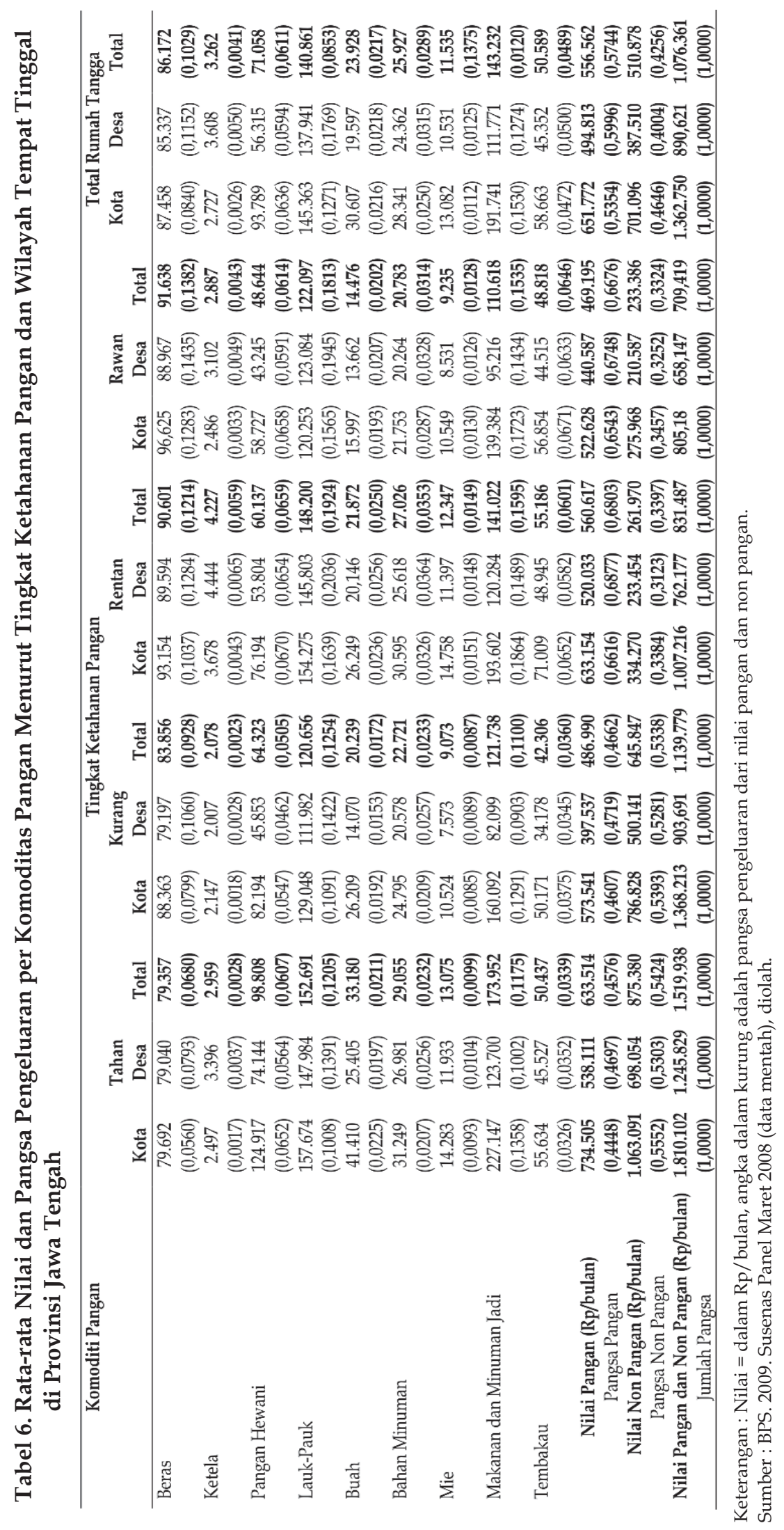


Pangsa pengeluaran bahan minuman, mie dan ketela adalah yang terkecil, masing-masing kurang dari 0,0200.

Rata-rata pangsa pengeluaran pangan menurut tingkat ketahanan pangan dan wilayah tempat tinggal (Tabel 6), secara total rumah tangga, rata-rata pangsa pengeluaran pangan rumah tangga di wilayah perkotaan lebih kecil $(0,5354)$ dibanding rumah tangga di wilayah pedesaan $(0,5996)$. Kondisi yang sama berlaku untuk rata-rata pangsa pengeluaran pangan menurut wilayah tempat tinggal dan tingkat ketahanan pangan, bahwa pada setiap kelompok rumah tangga menurut tingkat ketahanan pangan, rumah tangga di wilayah perkotaan mempunyai rata-rata pangsa pengeluaran pangan lebih kecil dibanding rumah tangga di wilayah pedesaan, kecuali pangsa pengeluaran makanan dan minuman jadi (lebih besar di wilayah pedesaan dibanding perkotaan).

Secara rinci dilihat per komoditas (Tabel 6), rumah tangga pada setiap tingkat ketahanan pangan, baik di perkotaan maupun di pedesaan, pangsa pengeluaran pangan terbesar adalah lauk-pauk dan makanan-minuman jadi, serta terkecil adalah ketela. Selain itu, kesemua pangsa pengeluaran pangan lebih rendah di perkotaan dibanding pedesaan, serta rumah tangga tahan dan kurang pangan, baik di perkotaan maupun di pedesaan, mempunyai pangsa pengeluaran pangan lebih kecil dari rumah tangga rentan dan rawan pangan. Perbedaan pendapatan rumah tangga menurut tingkat ketahanan pangan dan wilayah (Tabel 3) yang menyebabkan fenomena tersebut.

\section{Konsumsi Energi Menurut Tingkat Ketahanan Pangan}

Rata-rata jumlah konsumsi energi rumah tangga di Jawa Tengah sebesar $50.819 \mathrm{kkal} /$ rumah tangga/minggu, atau $13.847 \mathrm{kkal} /$ kapita, atau $1.978 \mathrm{kkal} /$ kapita/hari, dan sebesar 89,92 persen dari syarat kecukupan energi (Tabel 7)

Menurut tingkat ketahanan pangan (Tabel 7) menunjukkan jumlah konsumsi energi rumah tangga tahan dan rentan pangan (masingmasing sebesar $52.642 \mathrm{kkal} / \mathrm{rumah}$ tangga/ minggu dan $55.582 \mathrm{kkal} /$ minggu/rumah tangga) lebih besar dibanding rumah tangga kurang dan rawan pangan (masing-masing sebesar $42.384 \mathrm{kkal} / \mathrm{rumah}$ tangga/minggu dan 45.205 $\mathrm{kkal} /$ rumah tangga/minggu). Apabila dilihat konsumsi energi per kapita per hari menunjukkan pola yang sama, bahwa rumah tangga tahan dan rentan pangan (masing-masing sebesar 2.265 dan $2.275 \mathrm{kkal} /$ kapita/hari) lebih besar dibanding rumah tangga kurang dan rawan pangan (masing-masing sebesar 1.473 dan 1.498 kkal/kapita/hari).

Syarat kecukupan konsumsi energi sesuai Widyakarya Nasional Pangan dan Gizi VIII (WKNPG) tahun 2004 sebesar 2.200 kkal/kapita/hari (Ariani dan Purwantini, 2005). Berdasar syarat tersebut, maka konsumi energi rumah tangga tahan dan rentan pangan masingmasing sebesar 102,96 persen dan 103,42 persen dari syarat kecukupan, sedang rumah tangga kurang dan rawan pangan masing-masing sebesar 66,96 persen dan 68,11 persen dari syarat kecukupan (Tabel 6). Dilihat menurut wilayah tempat tinggal menunjukkan rata-rata konsumsi energi per kapita per hari pada setiap rumah tangga menurut tingkat ketahanan pangan, rumah tangga di pedesaan mempunyai nilai lebih besar dibanding dengan rumah tangga di perkotaan, kecuali pada rumah tangga kurang pangan, lebih besar di perkotaan dibanding di pedesaan (Tabel 7).

Dilihat per komoditas pangan (Tabel 7), secara total rumah tangga di Jawa Tengah, beras merupakan sumber utama konsumsi energi rumah tangga, ditunjukkan olehnya besarnya sumbangan beras terhadap konsumsi energi, yaitu sebesar $21.552 \mathrm{kkal} /$ rumah tangga/ minggu atau sebesar 42,41 persen. Disusul lauk-pauk (10.783 kkal/rumah tangga/minggu atau 21,22 persen) dan makanan-minuman jadi (9.548 $\mathrm{kkal} /$ rumah tangga/minggu atau 18,79 persen), bahan minuman dan pangan hewani (berturutturut $2.863 \mathrm{kkal} / \mathrm{rumah}$ tangga/minggu atau 5,63 persen untuk bahan minuman dan 2.523 $\mathrm{kkal} / \mathrm{rumah}$ tangga/minggu atau 4,96 persen untuk pangan hewani). Selanjutnya buah, mie, dan ketela merupakan proporsi terkecil (masing-masing antara 1.086-1.252 kkal/rumah tangga/minggu atau antara 2,14-2,46 persen) di antara komoditas pangan yang menyumbang pada konsumsi energi. 


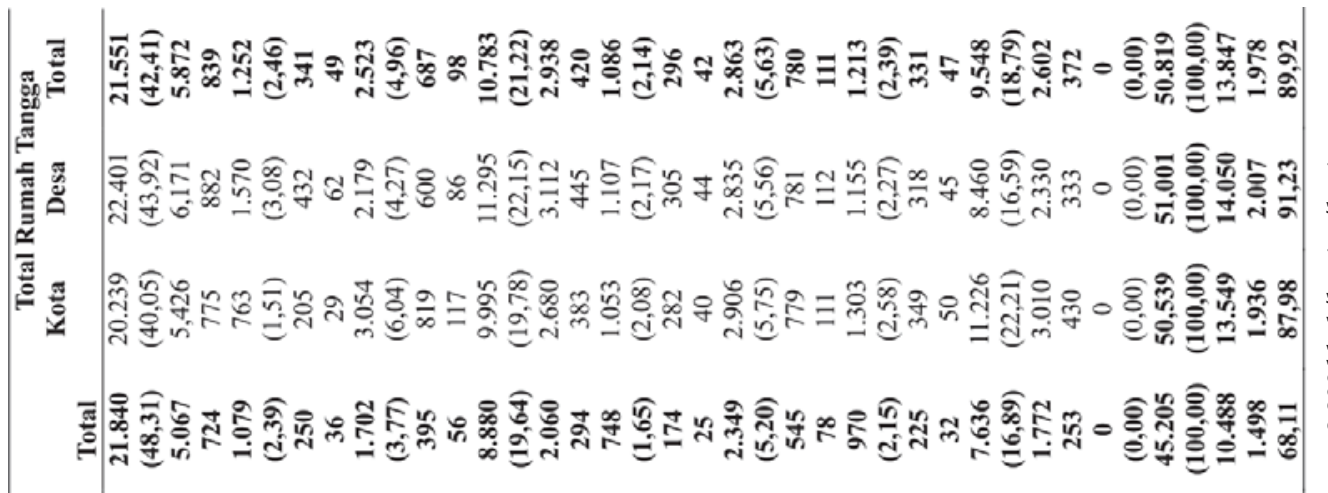

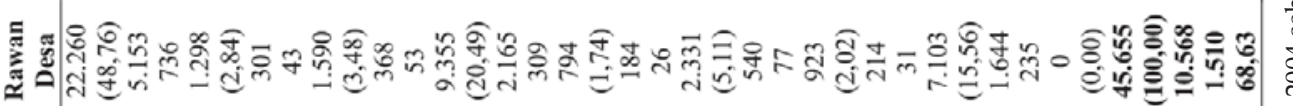

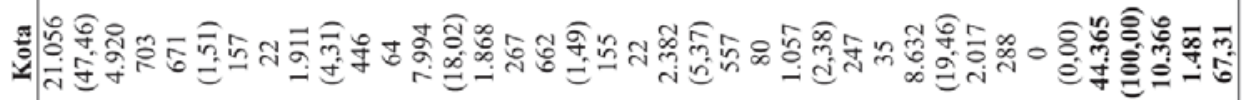

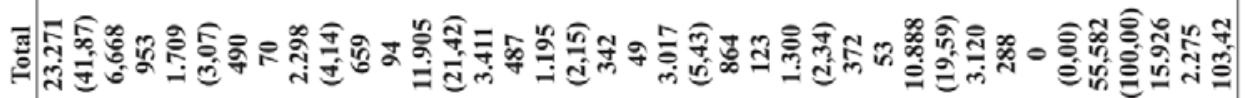

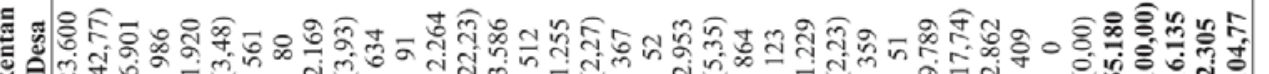

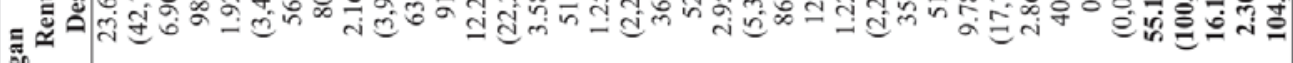

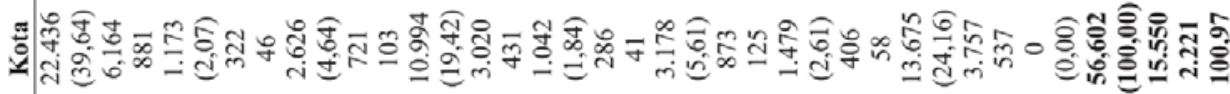

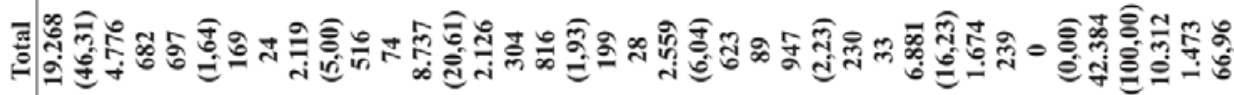
要

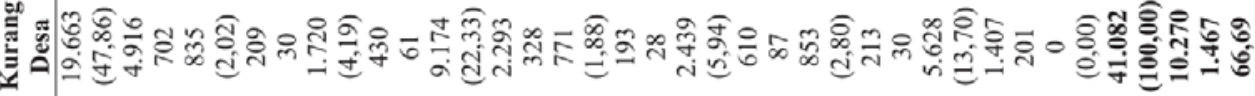

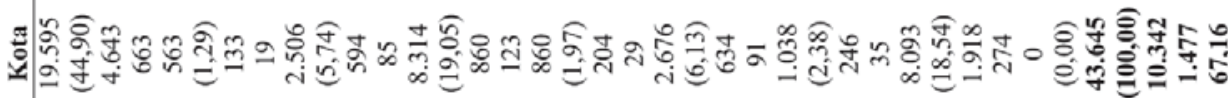

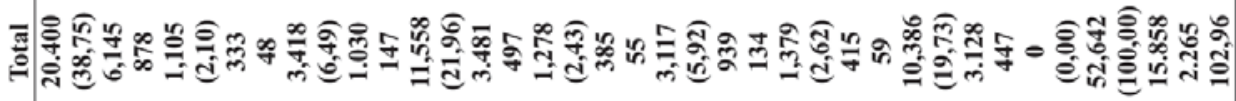

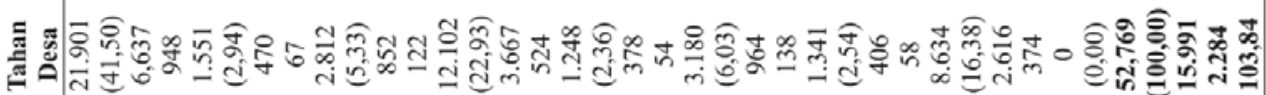

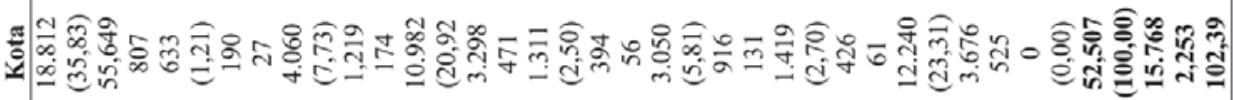

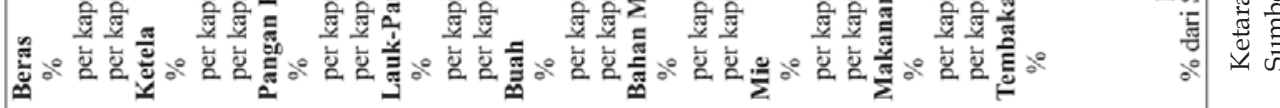


di pedesaan menunjukkan pola yang sama dengan total rumah tangga dan rumah tangga pada setiap tingkat ketahanan pangan, bahwa sumbangan terbesar adalah beras, disusul laukpauk, makanan-minuman jadi, pangan hewani dan bahan minuman, serta yang terkecil adalah buah, mie dan ketela.

Menurut wilayah tempat tinggal dan tingkat ketahanan pangan yang dicermati per komoditas pangan (Tabel 7) maka pada setiap rumah tangga menurut tingkat ketahanan pangan, sumbangan beras, ketela, lauk-pauk terhadap konsumsi energi lebih kecil pada rumah tangga di perkotaan (berturut-turut 35,85-39,64 persen untuk beras; 1,21-1,51 persen untuk ketela dan 18,02-20,92 persen untuk lauk-pauk) dibanding rumah tangga pedesaan (berturutturut 41,50-48,76 persen untuk beras; 2,02-3,48 persen untuk ketela dan 20,49-22,93 persen untuk lauk-pauk), sedangkan sumbangan pangan hewani dan makanan-minuman jadi terhadap konsumsi energi berlaku sebaliknya, rumah tangga di perkotaan (berturut-turut 4,317,73 persen untuk pangan hewani dan 18,5424,16 persen untuk makanan-minuman jadi) lebih besar dibanding rumah tangga pedesaan (berturut-turut 3,48-5,33 persen untuk pangan hewani dan 13,70-17,74 persen untuk makananminuman jadi).

Sumbangan pangan hewani dan makanan-

\section{SIMPULAN}

Perbedaan proporsi pengeluaran, baik pangan maupun non pangan, antara rumah tangga tahan dan kurang pangan dengan rumah tangga rentan dan rawan pangan, cukup besar (hampir dua kali lipat). Keadaan ini menunjukkan kesejahteraan rumah tangga pada kedua kelompok ketahanan pangan jauh berbeda. Pada setiap tingkat ketahanan pangan rumah tangga, pengeluaran rumah tangga untuk makanan dan minuman jadi menunjukkan proporsi tertinggi dibanding dengan kelompok pangan lain. Kondisi ini menunjukkan terjadinya perubahan konsumsi rumah tangga yang mengarah pada pola makan di luar rumah. Semakin tidak tahan pangan suatu rumah tangga, semakin tinggi proporsi pengeluaran untuk tembakau, atau rumah tangga rawan pangan mempunyai alokasi pengeluaran tembakau yang paling banyak dibanding dengan kelompok rumah tangga lainnya. Pada setiap kelompok rumah tangga menurut tingkat ketahanan pangan, rumah tangga di wilayah perkotaan mempunyai proporsi pengeluaran beras lebih kecil dibanding dengan rumah tangga di wilayah pedesaan.

Saran. (1) Berdasar hasil penelitain yang 
menunjukkan perbedaan kesejahteraan antara rumah tangga tahan dan kurang pangan dengan rumah tangga rentan dan rawan pangan, maka disarankan prioritas penanganan masalah ketahanan pangan harus diberikan pada kelompok rumah tangga rentan dan rawan pangan; (2) Meningkatnya pengeluaran rumah tangga untuk makanan dan minuman jadi perlu diwaspadai mengenai keamanan makanan jadi bagi kesehatan. Dengan demikian perlu pengawasan dan kontrol pemerintah sehingga pangan jajanan menjadi aman dan tidak membahayakan dari segi kesehatan; (3) Tingginya alokasi pengeluaran tembakau perlu diwaspadai mengingat rokok membahayakan kesehatan. Terlebih untuk rumah tangga rawan pangan, perlu mengurangi pengeluaran untuk tembakau dan dialihkan untuk pengeluaran pangan lain. Pemerintah perlu melakukan pelarangan melalui himbauan serta menyediakan tempat/ruangan khusus merokok di tempat publik, membuat peraturan bagi yang merokok di sembarang tempat, mensosialisasikannya dan menegakkannya dengan tegas.

\section{DAFTAR PUSTAKA}

Ariani, Mewa. 2008. Keberhasilan Diversifikasi Pangan Tanggung Jawab Bersama. Banten: Badak Pos, 16-22 Juni 2008. Halaman 2. http://banten.litbang.go.id. Diakses tanggal 18 Februari 2009.

Ariani, Mewa dan Tri Bastuti Purwantini. 2005. Analisis Konsumsi Pangan Rumah Tangga Pasca Krisis Ekonomi di Propoinsi Jawa Barat. Bogor: Puslitbang Sosial Ekonomi Pertanian. http://www.deptan.go.id. Diakses tanggal 1 September 2008.

Ariningsih, Ening. 2004. Analisis Perilaku Konsumsi Pangan Sumber Protein Hewani dan Nabati Pada Masa Krisis Ekonomi di Jawa. ICASERD Working Paper No.56. Pusat Penelitian dan Pengembangan Sosial Ekonomi Pertanian. Badan Penelitian dan Pengembangan Pertanian. Departemen Pertanian.

http://www.pse.litbang.deptan.go.id. Di- akses tanggal 3 Februari 2009.

BPS. 2008a. Pengeluaran untuk Konsumsi Penduduk Indonesia per Provinsi. Jakarta: Badan Pusat Statistik

BPS. 2007. Buku 3. Survei Sosial Ekonomi/Nasional. Jakarta: Badan Pusat Statistik.

BPS. 2008b. Kuesioner Survei Sosial Ekonomi Nasional 2008. Keterangan Pokok Rumah Tangga dan Anggota Rumah Tangga. VSENP2008.K. Panel Maret 2008. Jakarta: Badan Pusat Statistik.

BPS. 2008c. Kuesioner Survei Sosial Ekonomi Nasional 2008. Modul Konsumsi/Pengeluaran dan Pendapatan Rumah Tangga. VSENP08.M. Panel Maret 2008. Jakarta: Badan Pusat Statistik.

BPS. 2008d. Raw Data Survei Sosial Ekonomi/ Nasional Provinsi Jawa Tengah. Modul Konsumsi/Pengeluaran Rumah Tangga dan Pendapatan. Panel Maret 2008. Jakarta : Badan Pusat Statistik.

LIPI (Lembaga Ilmu Pengetahuan Indonesia), 2004. Widyakarya Nasional Pangan dan Gizi VIII. "Ketahanan Pangan dan Gizi di Era Otonomi Daerah dan Globalisasi". Jakarta, 17-19 Mei 2004. http://www.google. com. Diakses tanggal 5 Juni 2009.

Maxwell, D; C. Levin; M.A. Klemeseau; M.Rull; S. Morris and C.Aliadeke. 2000. Urban Livelihoods and Food Nutrition Security in Greater Accra, Ghana. IFPRI in Collaborative with Noguchi Memorial for Medical Research and World Health Organization. Research Report No.112. Washington, D.C.

Purwaningsih, Yunastiti. 2008. Ketahanan Pangan: Situasi, Permasalahan, Kebijakan dan Pemberdayaan Masyarakat. Jurnal Ekonomi Pembangunan. Surakarta: Balai Penelitian dan Pengembangan Ekonomi Fakultas Ekonomi Universitas Muhammadiyah Surakarta. Vol. 9 No.1 Hal 1-27.

Purwaningsih, Yunastiti. 2010. Analisis Permintaan Pangan pada Berbagai Tingkat Ketahanan Pangan Rumah Tangga di 
Provinsi Jawa Tengah. Disertasi Program Doktor (S3) Ekonomi Pertanian UGM Yogyakarta.

Rachman, Handewi P.S, Mewa Ariani dan TB Purwantini. 2005. Distribusi Provinsi di Indonesia Menurut Derajat Ketahanan Pangan Rumah Tangga. Bogor: Pusat Analisis Sosial Ekonomi dan Kebijakan Pertanian. http://www.deptan.go.id. Diakses tanggal 13 Juni 2008.
Saliem, Handewi P dan Ening Ariningsih. 2008. Perubahan Konsumsi dan Pengeluaran Rumah Tangga di Perdesaan: Analisis Data SUSENAS 1999-2005. Makalah disampaikan pada Seminar Nasional "DINAMIKA PEMBANGUNAN PETANIAN DAN PERDESAAN". Bogor: Pusat Analisis Sosial Ekonomi dan Kebijakan Pertanian. 19 November 2008. http://google.com. Diakses 5 Juni 2000. 